\title{
MEDIA PEMBELAJARAN INTERAKTIF ADOBE FLASH PADA LPP SANGGAR SAKI
}

\author{
Yanuar Herlambang, S.Sn., M.Ds.,ACA \\ Dosen Program Studi Manajemen Informatika \\ Politeknik LP3I Bandung \\ e-mail : yanuarherlambang.plb@yahoo.com
}

\begin{abstract}
Abstrak : Metode belajar sambil berinteraktif menjadi pilihan utama untuk meningkatkan suatu kegiatan belajar mengajar menuju tercapainya hasil belajar yang optimal. Aplikasi pembelajaran interaktif dengan konsep multimedia sedang menajdi trend dikalangan pengembang aplikasi pendidikan saat ini. Salah satu media interaktif yang menarik dan media animasi. Penggunaan animasi sangat membantu dalam menjelaskan berbagai visualisasi konsep pembelajaran yang sukar dijelaskan secara konvensional. Selain itu menggunakan media animasi dapat meningkatkan minat belajar dan pemahaman bagi siswa.
\end{abstract}

Pengembangan media pembelajaran yang dibuat dengan software flash telah banyak dikembangkan oleh para pendidik dan telah ditayangkan pada LCD dalam upaya meningkatkan pemahaman siswa terhadap materi.

Adobe Flash adalah salah satu program yang dapat dimanfaatkan untuk membuat media pembelajaran yang cukup menarik melalui animasi interaktif..

Kata Kunci : metode pembelajaran interaktif, metode interaktif, adobe flash

\section{Pendahuluan}

Selama ini sistem pengajaran khususnya di negara Indonesia masih di lakukan secara manual dengan menggunakan media yang konvensional seperti kertas (buku) dan papan tulis. Sudah seharusnya sistem pembelajaran mengalami pembaharuan dengan memanfaatkan perkembangan teknologi informasi sehingga bisa meningkatkan mutu pendidikan di Indonesia.

Sekarang ini pengenalan komputer kepada anak-anak menjadi hal yang menarik dan penting. Perkembangan teknologi informasi yang semakin pesat telah mempengaruhi perkembangan komputer yang semakin pesat pula. Sehingga dapat dikatakan, dalam perkembannya kedua teknologi ini saling berkaitan erat dan akan senantiasa berjalan beriringan. Sama seperti bidang lainnya, perkembangan komputer erat kaitannya dengan dunia pendidikan. Banyak pekerjaan di dalam dunia pendidikan yang dibantu pekerjaannya dibantu oleh komputer, mulai dari mengetik, berhitung, browsing dari internet dan sebagai media pembelajaran. 


\section{Sistem Yang Berjalan}

\section{Flowchart Media Pembelajaran}

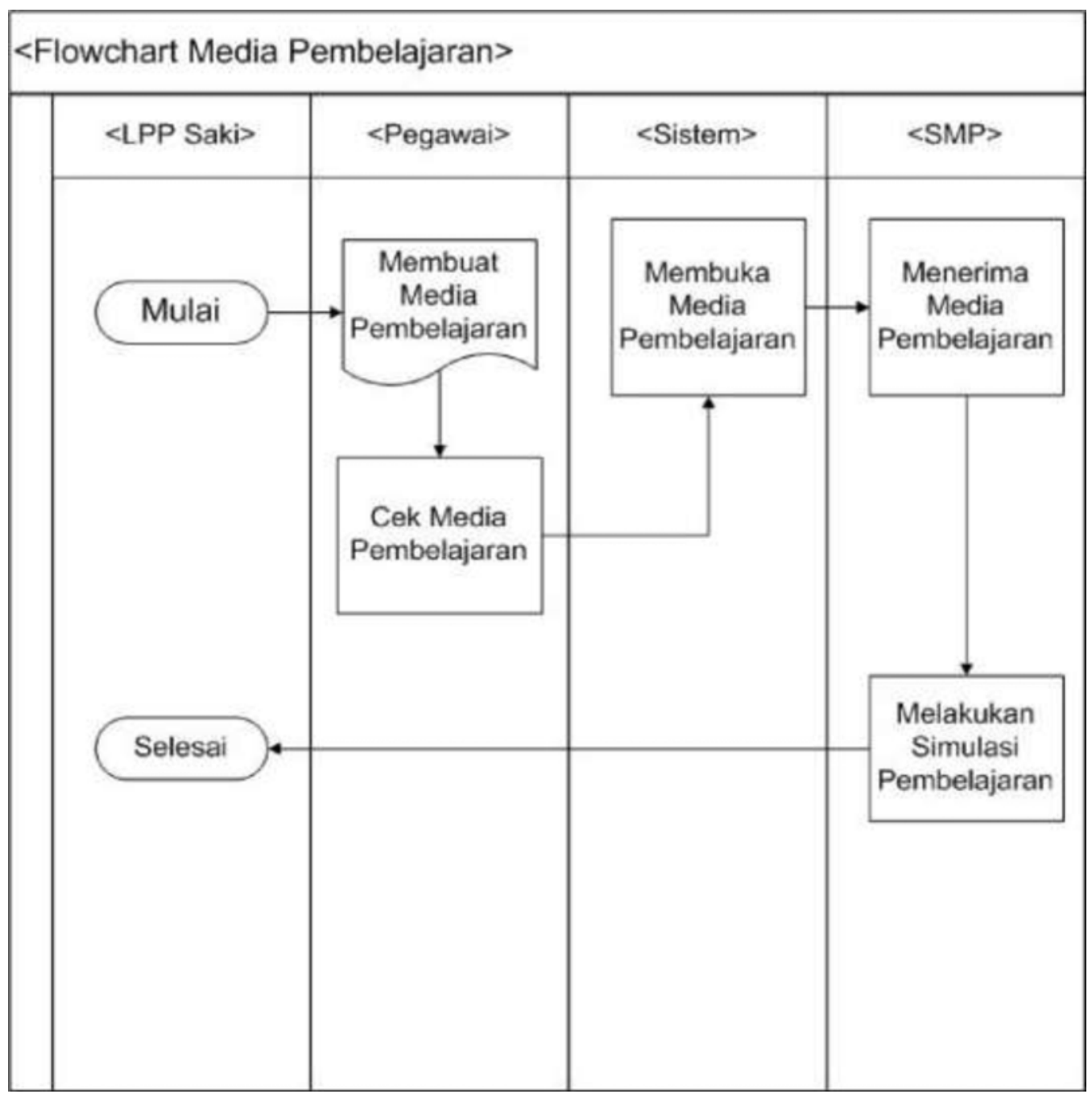

\section{Kebutuhan Pengguna}

Berdasarkan hasil wawancara, maka penulis melakukan pengamatan langsung pada perusahaan dengan menyediakan pertanyaan kepada yang bersangkutan dan memperoleh kebutuhan pengguna sebagai berikut:

1. Membuat Media Pembelajaran Interaktif Adobe Flash CS5

2. Menggunakanya untuk siswa yang masih pemula

\section{Ruang Lingkup Produk}

Mengingat permasalah yang ada terlalu luas, maka penulis membatasi masalah sebagai berikut:

1. Aplikasi ini hanya di gunakan untuk pemula yang kurang paham dengan Adobe Flash. 
2. Bahasa yang digunakan untuk membuat aplikasi ini yaitu sebagian besar menggunakan pemerograman Adobe Flash dengan bahasa yang lebih di mengerti.

\section{Pembahasan}

LPP Sanggar Saki merupakan usaha yang bergerak dalam bidang pendidikan non formal pada segmen anak-anak dari TK s/d SMA dengan program gambar, melukis, calistung (GAMECI), bimbingan belajar iqro, sempoa dengan tujuan untuk membantu anak-anak mendapatkan pendidikan yang lebih baik wadah anak kreatif $\&$ inovatif serta menjadi juara. Dengan berjalannya waktu kemudian sanggar saki membuka program lain dalam bidang bahasa dan komputer, dalam hal ini Sanggar Saki memiliki komitmen selain segmen anak-anak Sanggar Saki ingin membantu masyarakat mendapatkan keterampilan dalam bidang komputer dan bahasa untuk masyarakat masyarakat.

Pendidikan Sanggar Saki ini berdiri pada tanggal 03 september 2014 dengan nama Sanggar Saki di Jalan Raya Sadang Sari No.2 (Sadang Serang) Bandung. Pada pembukaan acara Sanggar Saki di hadiri segenap pimpinan Sanggar Saki dan karyawan Sanggar Saki. Sanggar Saki ini didirikan oleh Bapak Edi Casnadi sebagai komisaris, mencetus program dan ibu atikah sebagai komisaris juga, pemberi ide dan pemberian nama SAKI. Tetapi hal ini juga didukung oleh karyawan Sanggar Saki yang luar biasa sebagai penyempurna lembaga ini. Dalam waktu 1 minggu Sanggar Saki sudah memiliki murid lebih dari 30 siswa, hal ini menjadikan prestasi tersendiri dan kami semakin semangat dalam memperbaiki manajemen dan kualitas.

Sanggar Saki ini berdiri di bawah naungan Yayasan CSA dan lembaga pendidikan CSA Interganesha. Hal ini CSA merupakan memberikan sharing pengetahuan, program, hubungan internasional, hukum, pegawai dan support segala aktivitas serta pendanaan.

Sanggar Saki merupakan pendidikan non formal yang berbeda dengan sanggar lain dikarenakan Sanggar Saki memiliki komitmen untuk memberikan kualitas, karakter akhlak yang baik menuju prestasi dan juara serta berbasis standart internasional serta beradaptasi dan mengadopsi teknologi yang terupdate.

\subsection{Pengguna Produk}

Setelah melakukan penelitian yang berhubungan dengan system belajar di LPP Sanggar Saki , dapat diketahui bahwa system belajar masih manual dan berpatok pada buku sehingga siswa akan memperhatikan penjelasan dari pengajar tentang materi yang akan di pelajari lalu mereka melihat buku untuk membuka dan memahami gamar dan langkah - langkah materi yang di pelajari. Oleh karena itu penulis membuat media pembelajaran interaktif sebagai media pembelajaran di LPP Sanggar Saki. Dalam pembuatan media pembelajaran interaktif penulis membuat sebuah tutorial tentang adobe flash CS5 buat pemula secara mendasar untuk mengenal fungsi - fungsi dan arti adobe flash CS5 yang dikemas dalam aplikasi adobe flash dimana para murid les dapat lebih mudah mempelajari materi.

\subsection{Prosedur Sistem Usulan}

Setelah mengetahui gambaran sistem lama maka dapat dilakukan pembaharuan dalam sistem yang berjalan. Dengan usulan sistem yang baru sehingga dalam kebutuhankebutuhan pengajar selama bekerja dalam sistem tersebut, dapat lebih menarik, di saat memberikan pengertian yang interaktif kepada siswa. 


\section{Usecase Diagram Usulan}
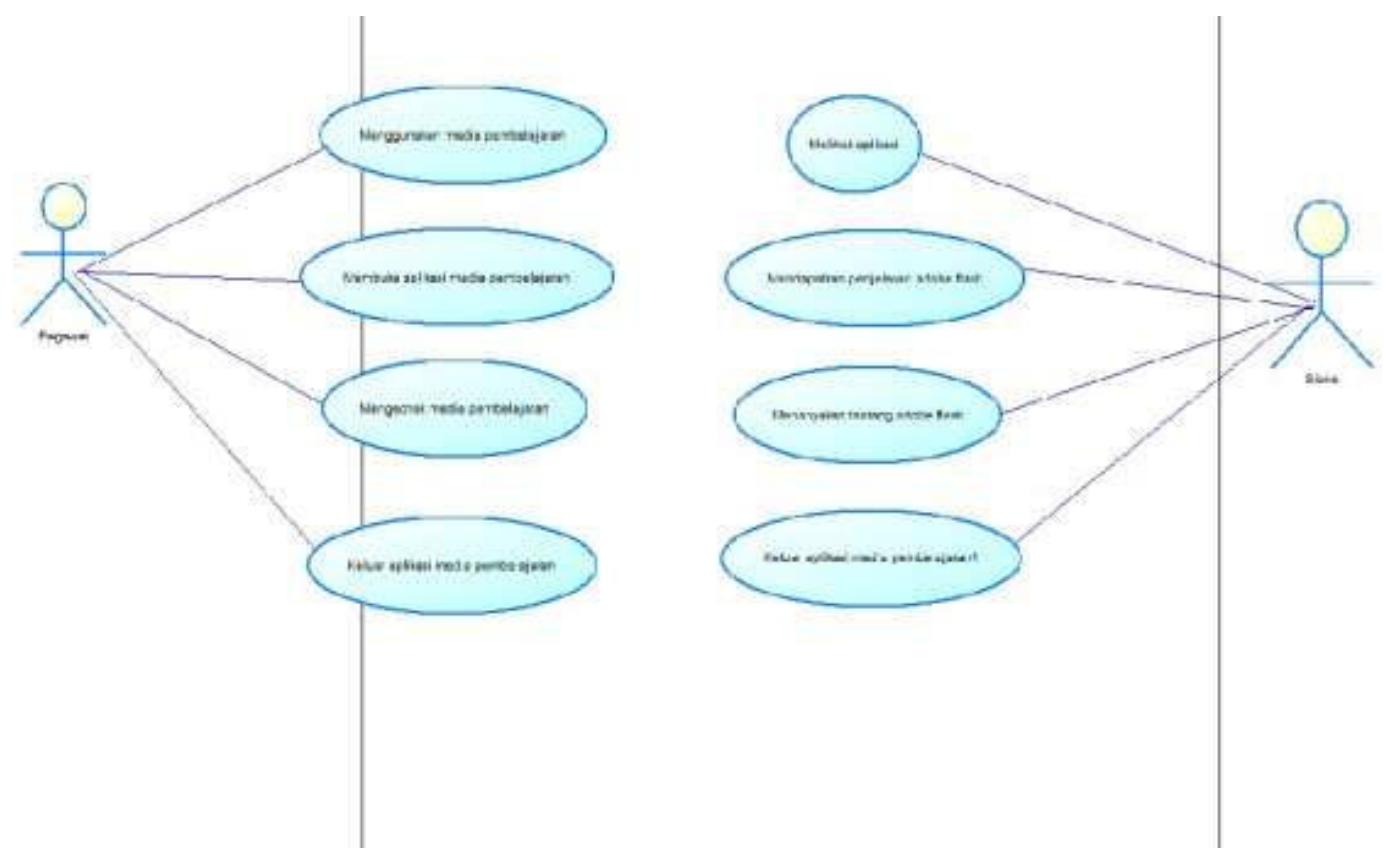

Sistem Usulan Penggunaan Media Pembelajaran Interaktif

\section{Perancangan Aplikasi}

Dalam perancangan aplikasi ini, aplikasi yang digunakan penulis dalam pembuatan media pembelajaran interaktif ini yaitu menggunakan aplikasi Adobe Flash CS5 karena program yang didesain khusus oleh Adobe dan bitmap yang sangat menarik untuk keperluan pembangunan informasi produk yang lebih interaktif dan edukatif. Diperlukan aplikasi pendukung yang mampu membuat media tersebut menarik dan terkonsep yaitu menggunakan :

\section{Spesifikasi Sofware dan Hardware}

1. Perangkat lunak (Sofware) yang diunakan pada saat perancangan aplikasi adalah :
a. OS Windows 7 64-bit
b. Adobe Flash CS 5
c. Adobe Photoshop
d. Corel Draw X6
e. Microsoft Visio 2007
f. Paint
g. Mozila Firefox 
2. Perangkat keras (hardware) yang digunakan pada saat perancanganaplikasi adalah:

a. Intel Pentium Core i7 $2.10 \mathrm{GHz}$

b. RAM dengan kapasitas $8.00 \mathrm{~GB}$

c. Harddisk dengan kapasitas 1 Tera

d. Display Mode $1036 \times 768$

e. Monitor

f. Wifi

\section{Perancangan Flowchart}

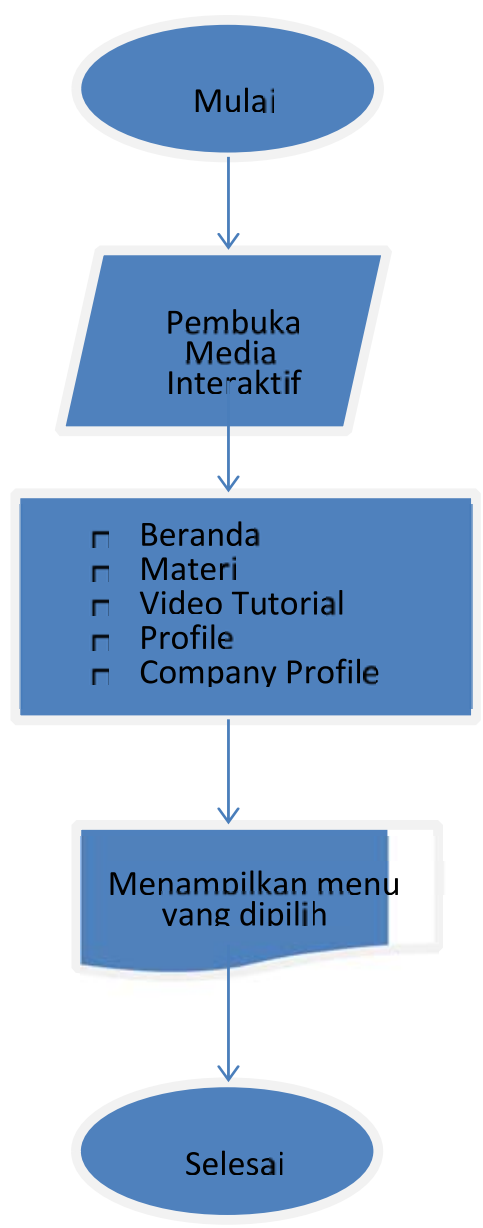

Flowchart Proses Media Pembelajaran Interaktif. 


\section{Perancangan Struktur Menu}

\section{Sitemap}

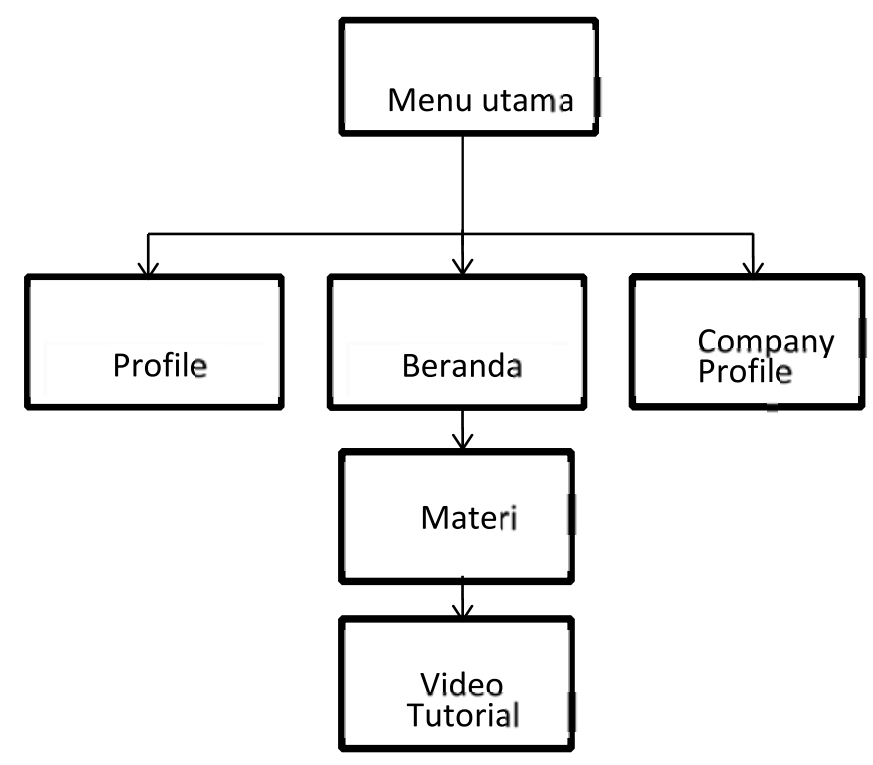

Gambar Struktur Menu Program

\section{Perancangan Antar Muka Storyboard}

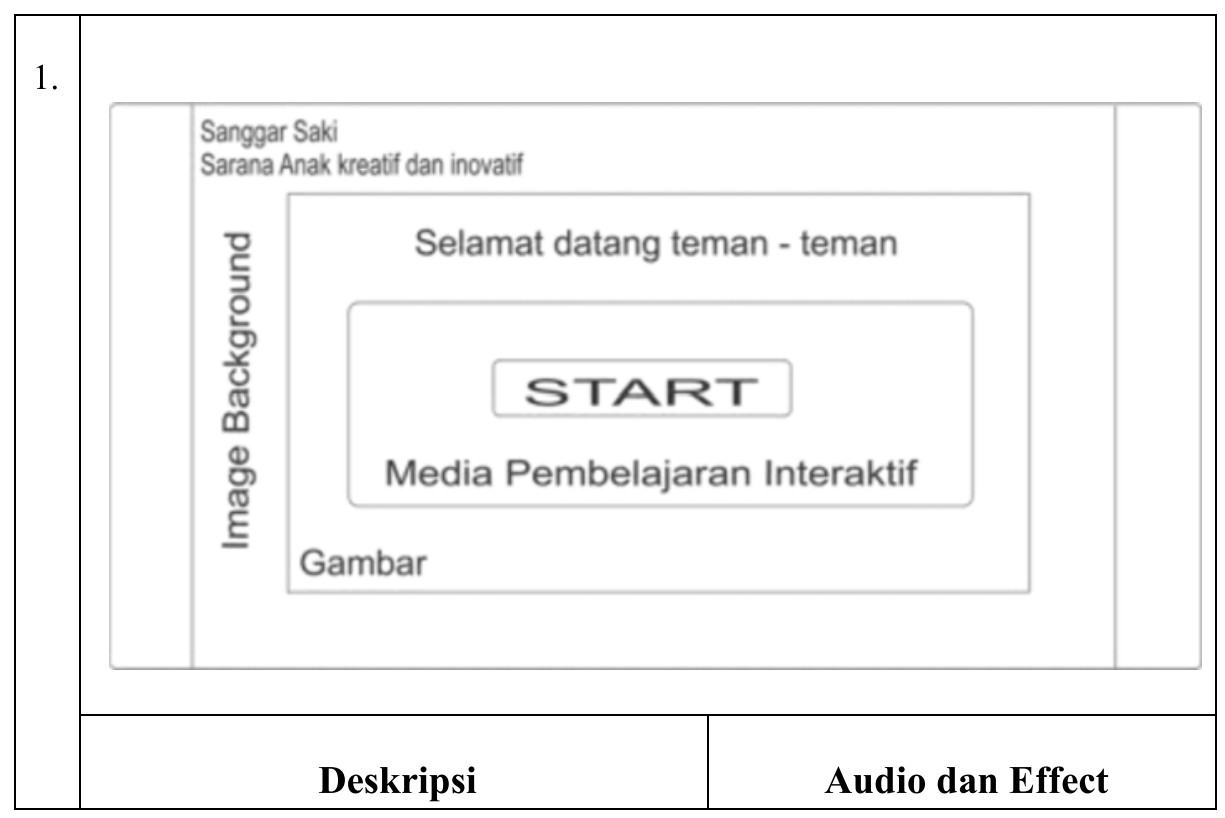




\begin{tabular}{|l|l|l|}
\hline $\begin{array}{l}\text { Tampilan Pembuka Media } \\
\text { pembelajaran }\end{array}$ & $\begin{array}{l}\text { Tombo masuk akan } \\
\text { berbunyi saat kursor } \\
\text { mengenai tombol, juga } \\
\text { akan berbunyi saat } \\
\text { Terdapat tombol start untuk } \\
\text { masuk ke menu utama }\end{array}$ & \begin{tabular}{l} 
tombol ditekan \\
\hline
\end{tabular} \\
\hline
\end{tabular}

Gambar Tampilan Pembuka Media Pembelajaran

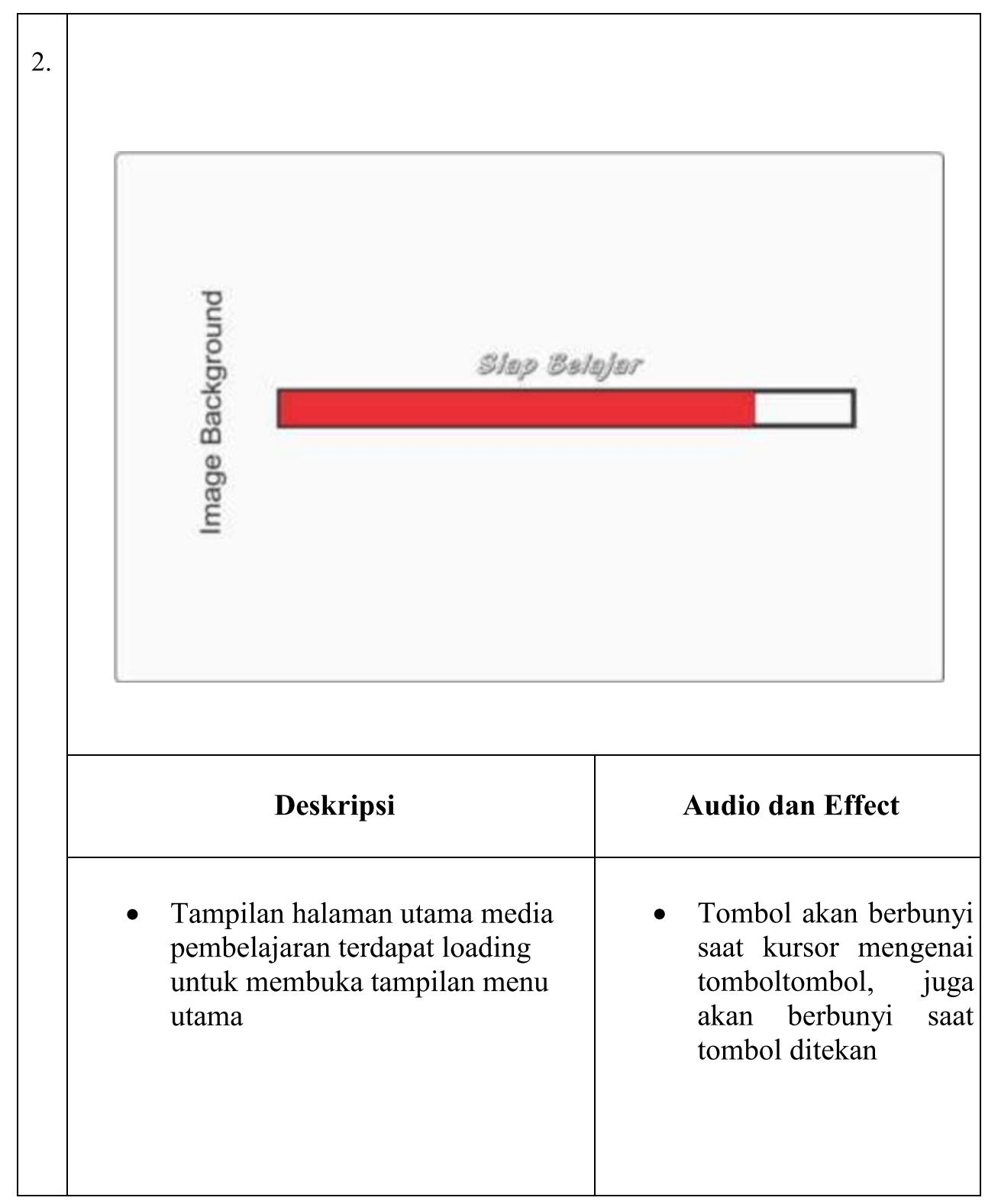

Gambar Loading 


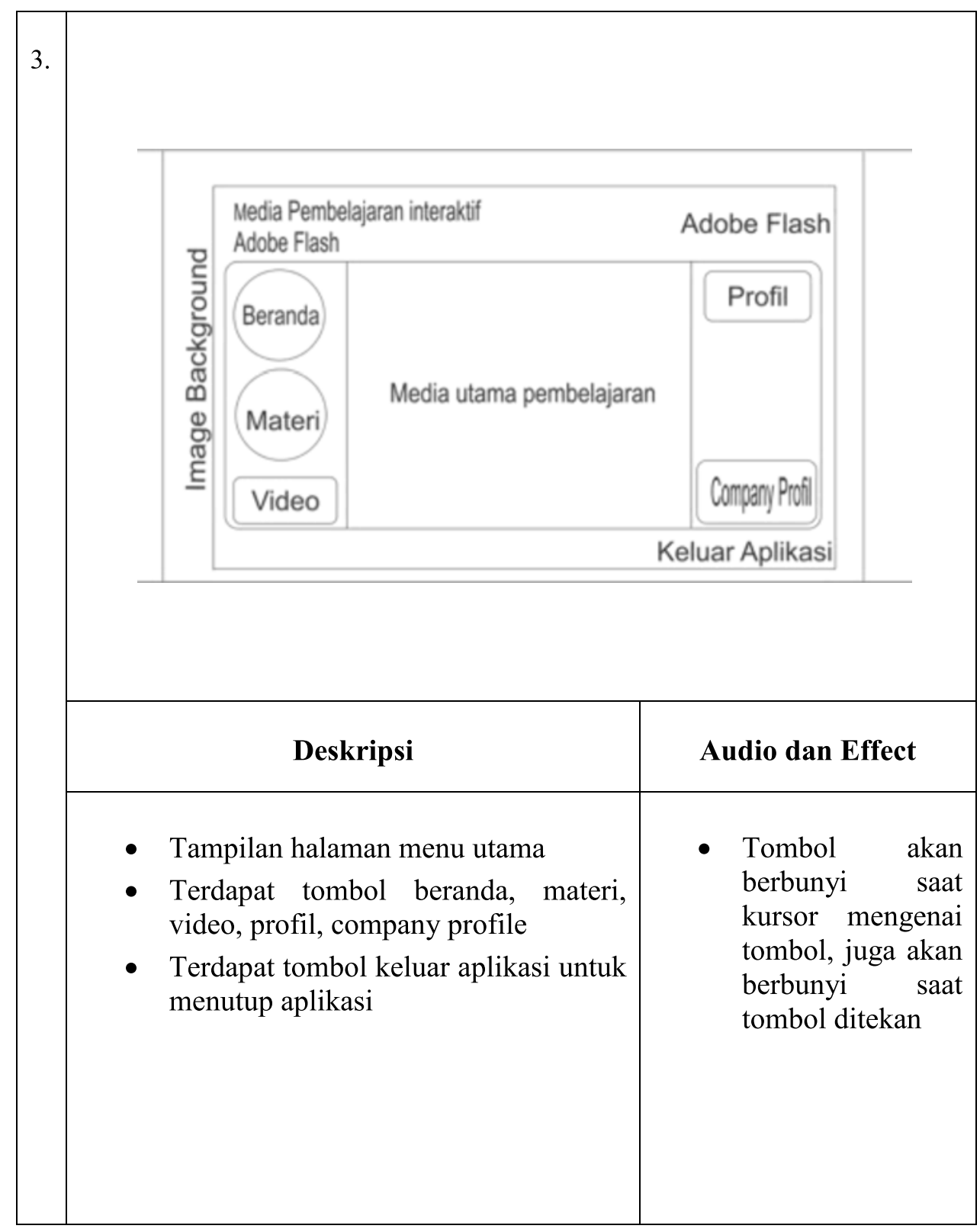

Gambar Halaman Media Utama Pembelajaran 


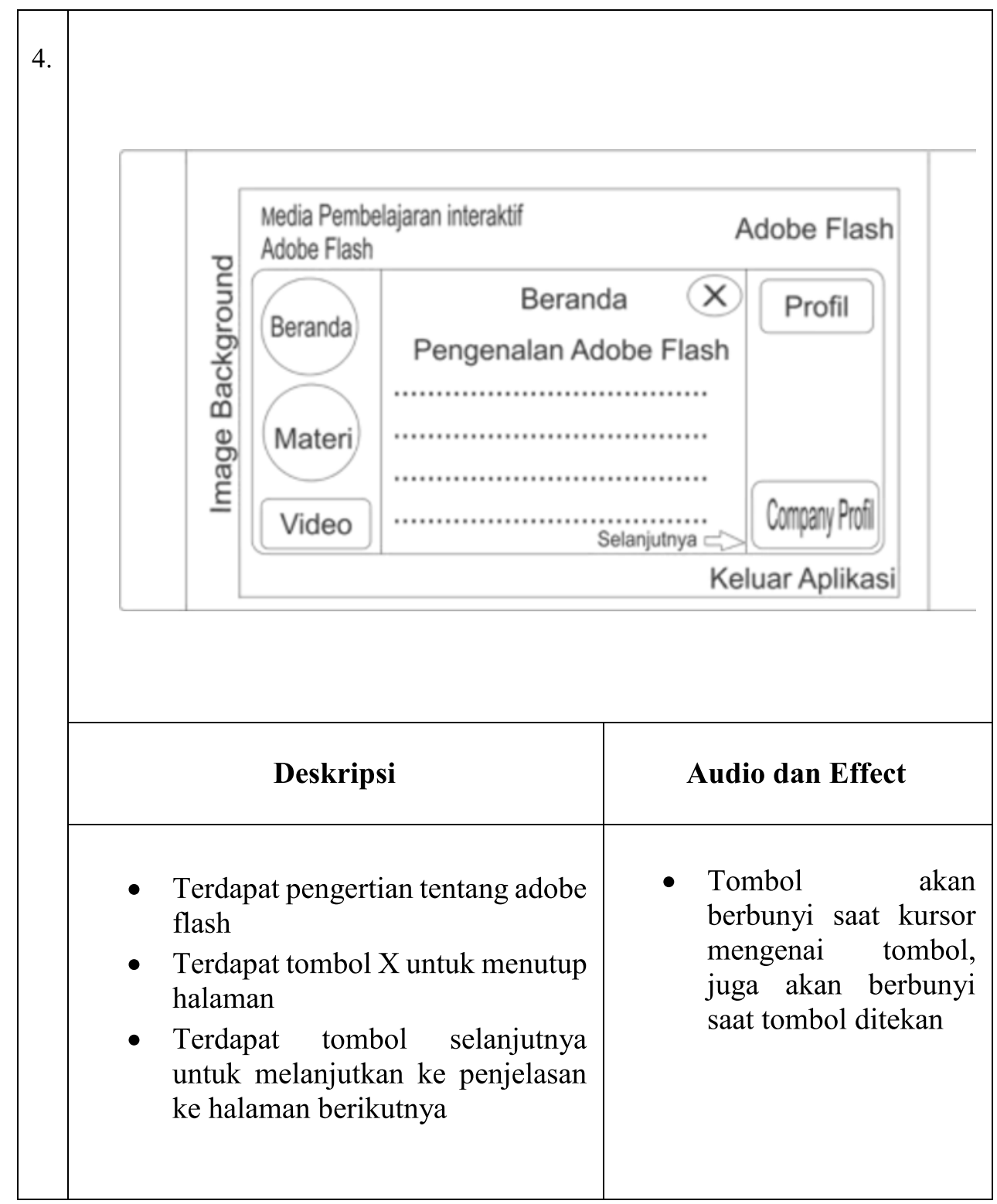

Gambar Halaman Beranda 


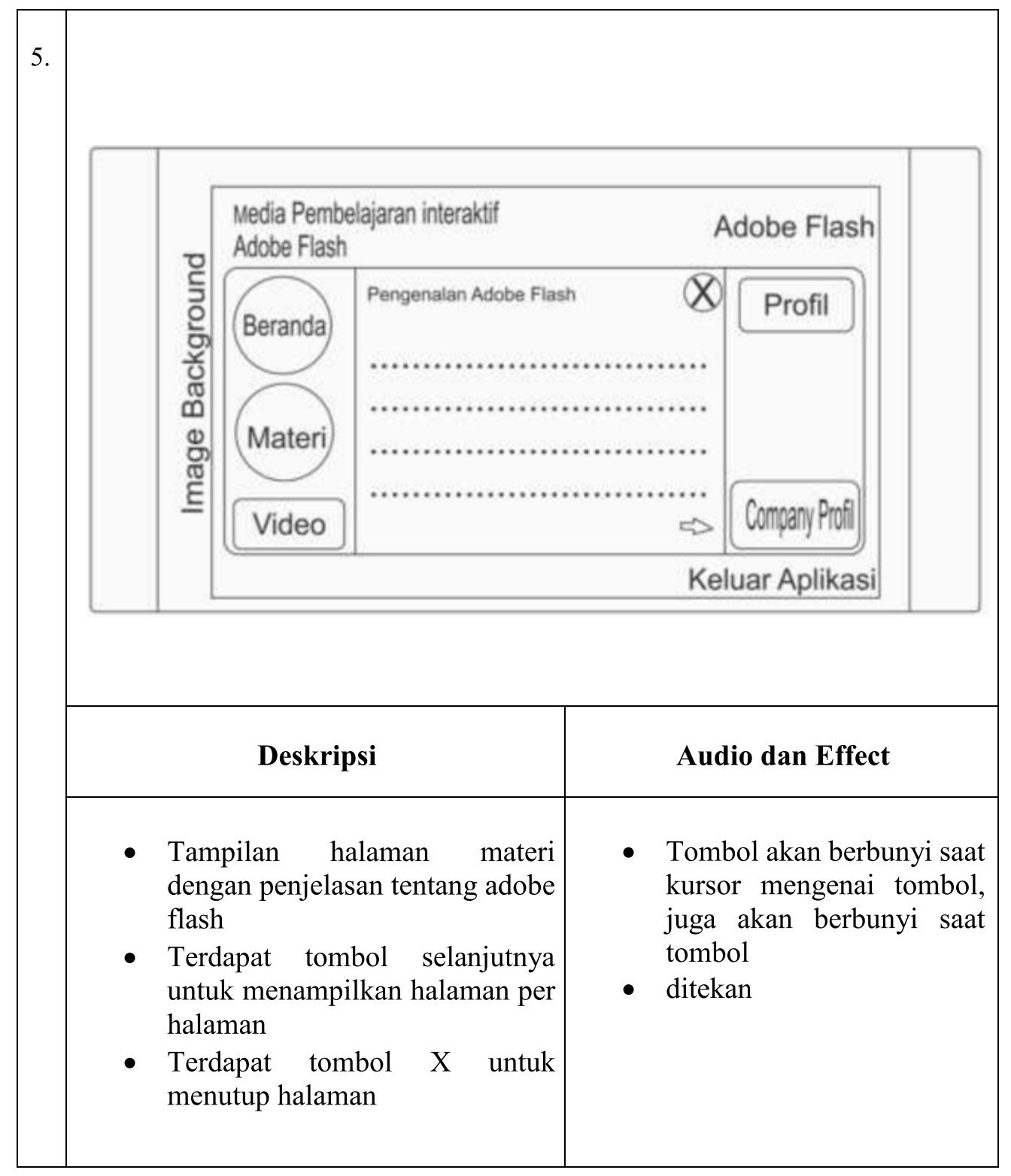

Gambar Halaman Materi 


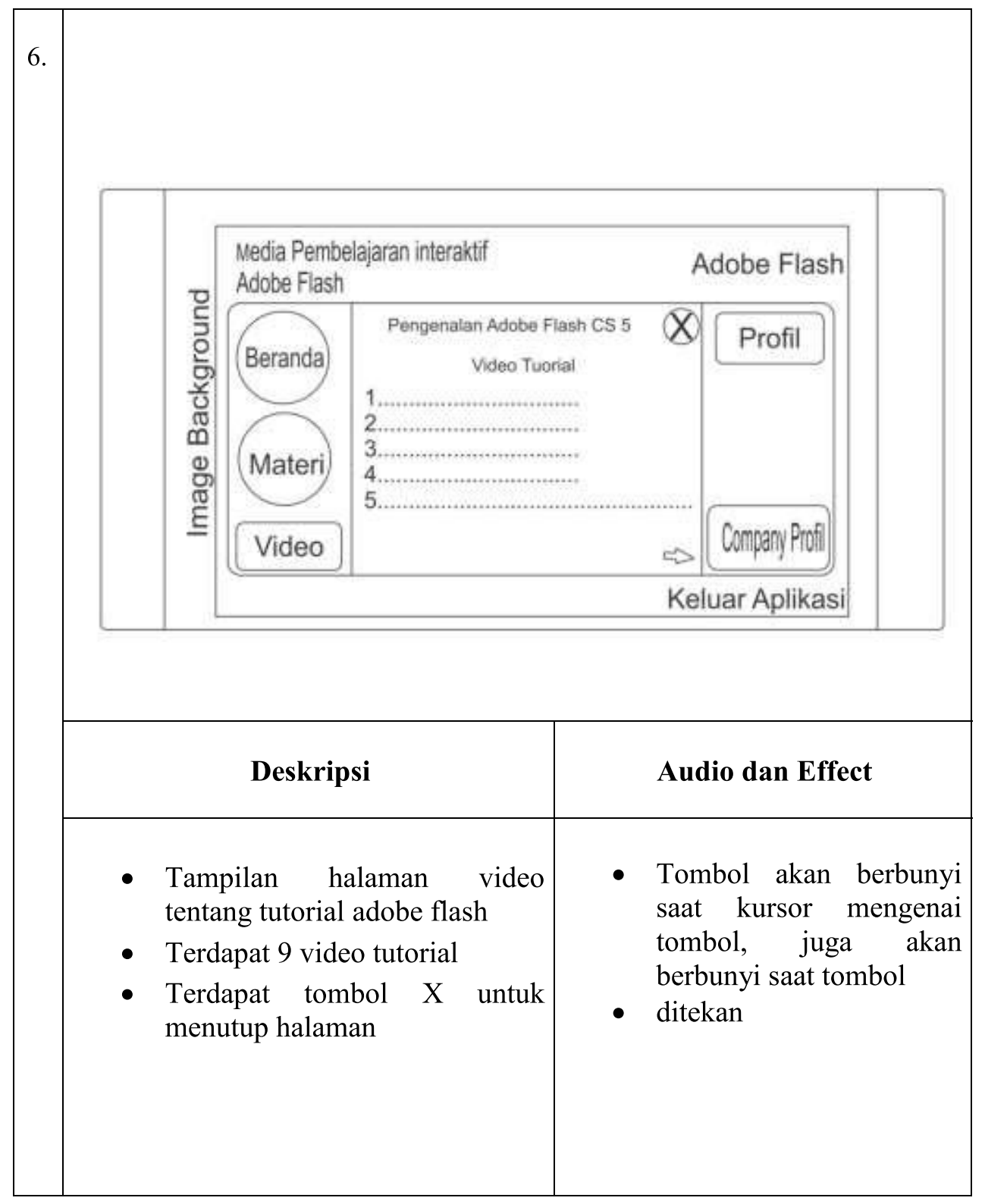

Gambar Halaman Video 


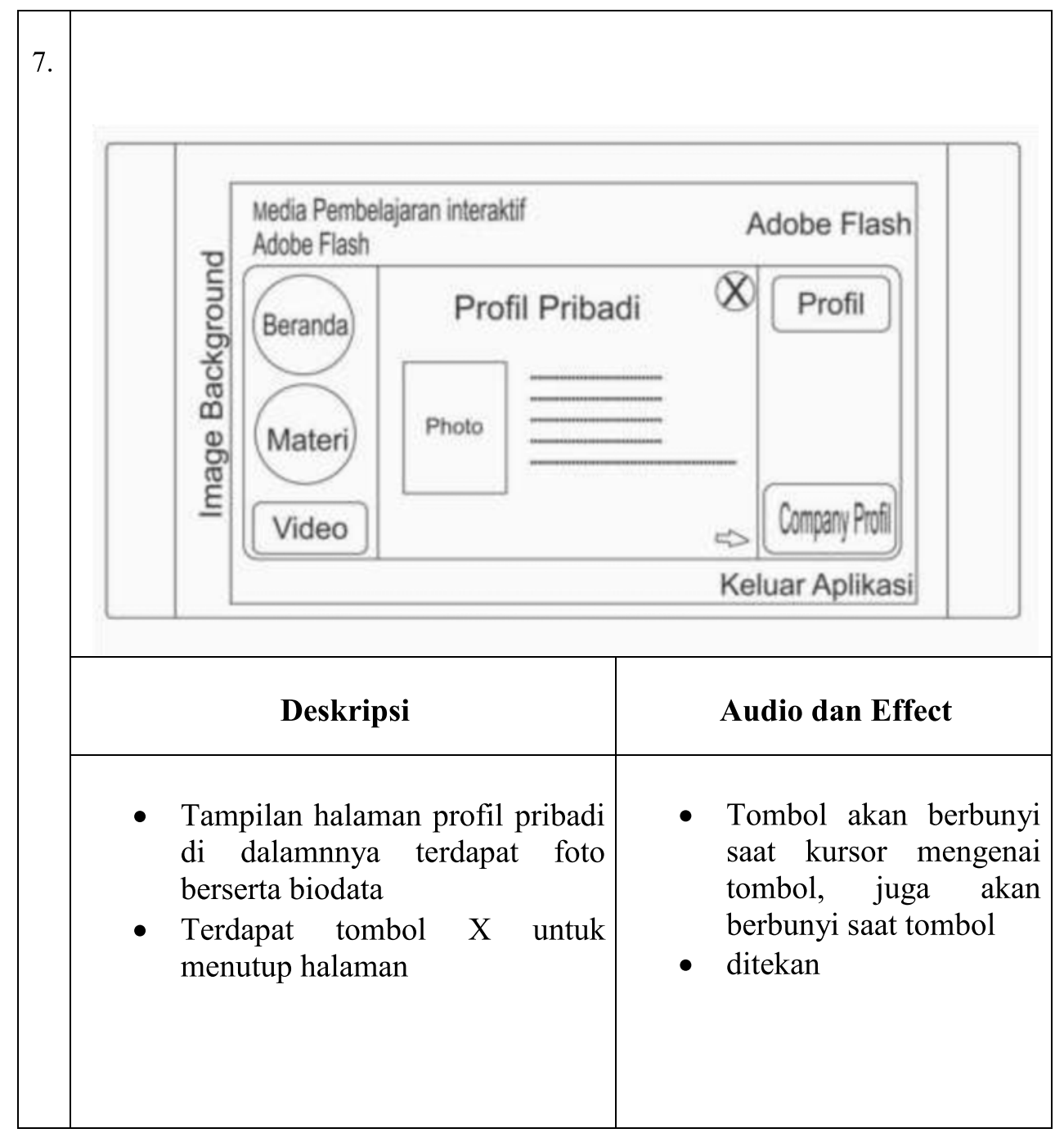

Gambar Halaman Profil Pribadi 


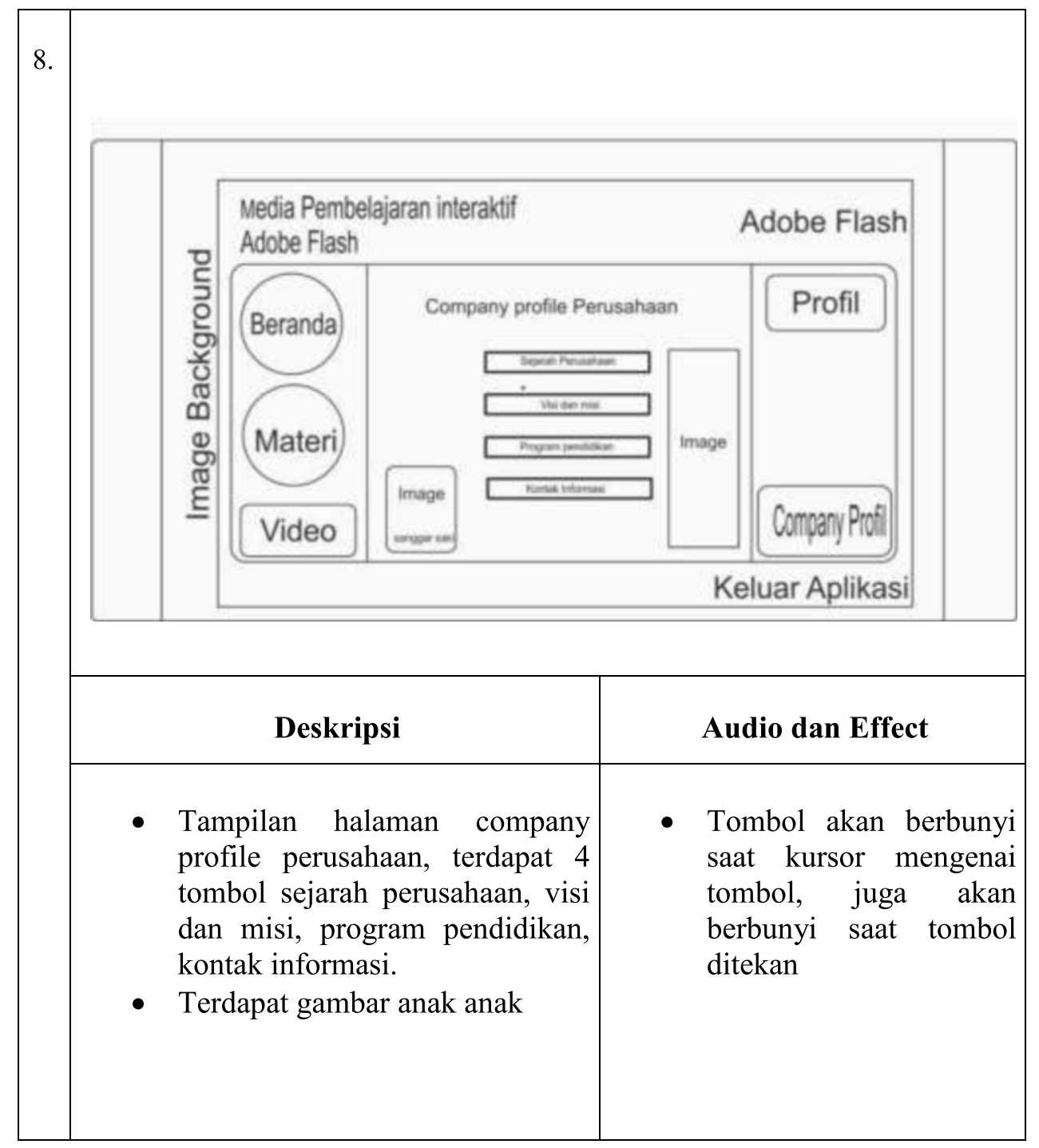

Gambar Halaman Company Profile Perusahaan 


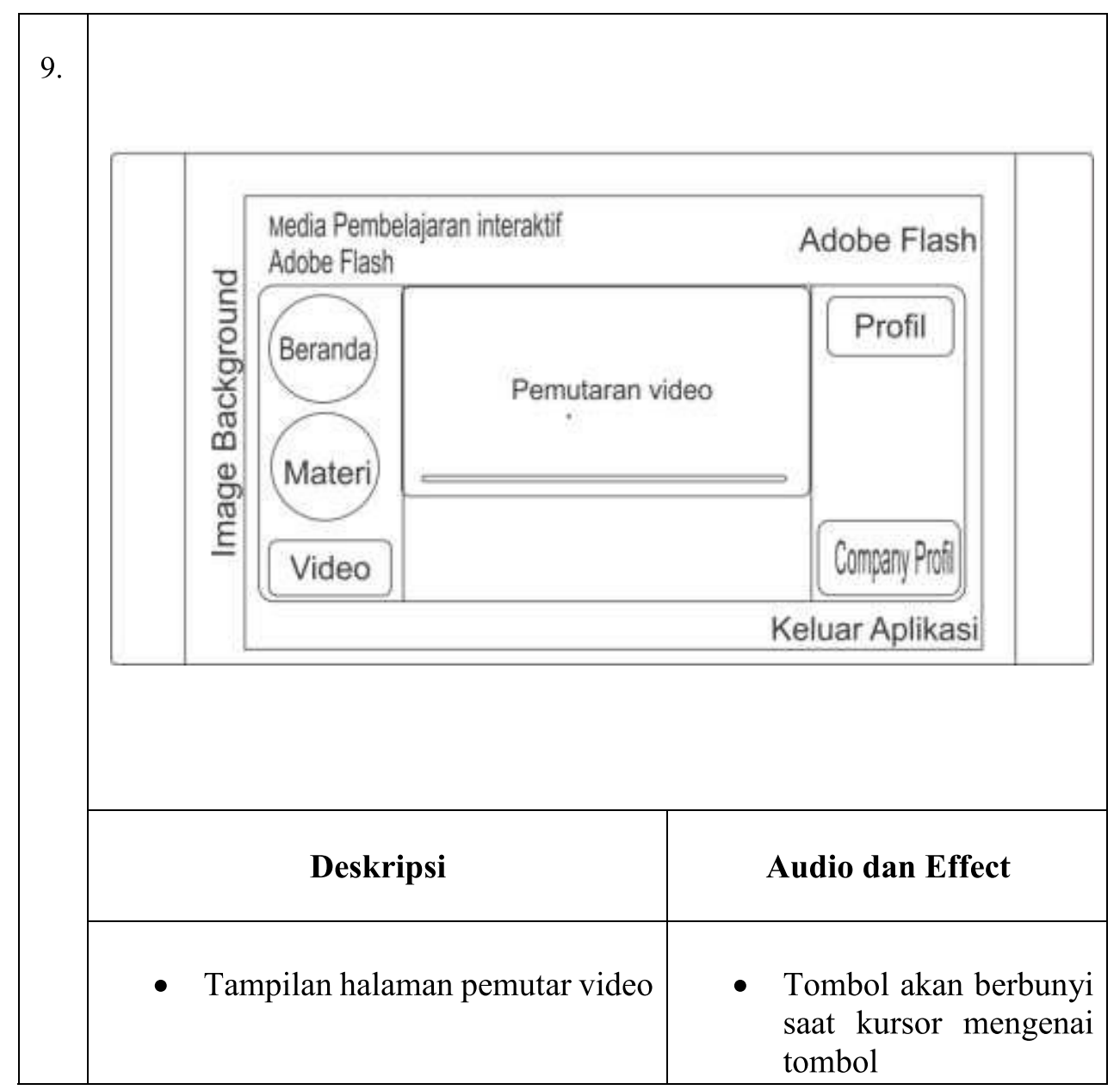

Gambar Halaman Pemutar Video tutorial

\section{Kesimpulan}

Dalam suatu proses belajar mengajar, ada unsur yang amat penting yaitu media pembelajaran. Pemilihan media pembelajaran tertentu akan mempengaruhi jenis media pembelajaran yang sesuai, meskipun masih ada berbagai aspek lain yang harus diperhatikan dalam memilih media.

Media mempunyai manfaat dan fungsi sebagai sarana bagi guru untuk dapat menyampaikan materi pelajaran menjadi lebih menarik, tidak hanya monoton, siswa tidak hanya diajak untuk berhayal dan membayangkan saja tetapi siswa dapat melihat kenyataan walaupun hanya melalui gambar ataupun video.

\section{Daftar Pustaka}

[1] Arsyad, A., 2013, Media Pembelajaran. Jakarta: PT. Raja Grafindo Persada.

[2] Kustandi, C. dan Sutjipto, B., 2011. Media Pembelajaran: Manual dan Digital Bogor: Ghalia Indonesia.

[3] Komara E., 2014. Belajar dan Pembelajaran Interaktif, Bandung: PT Refika Aditama. 
[4] Kaswan, 2011. Pelatihan dan Pengembangan untuk Meningkatkan Kinerja SDM, Bandung: Alfabeta.

[5] Masnur, N.H. dan Saliwangi B., 1987. Dasar-dasar Interaksi Belajar Mengajar Bahasa Indonesia, Bandung: CV. Jemmars.

[6] Moekijat, 1991, Latihan dan Pengembangan Sumber Daya Manusia, Bandung: CV. Mandor Jaya.

[7] Moekijat, 1995, Manajemen Personalia dan Sumber Daya Manusia. Bandung: CV. Mandor Jaya.

[8] Malik, O., 2000. Pengembangan Sumber Daya Manusia, Manajemen Pelatihan Ketenagakerjaan: Pendekatan Terpadu, Jakarta: Bumi Aksara.

[9] Notoatmodjo, S., 1998, Pengembangan Sumber Daya Manusia, Jakarta: PT. Rineka Cipta. 